\title{
Fact about Stomach Cancer Patients in Rural Area
}

Tadao ОвA, M. D.

Directer, Kumiai General Hospital Gifu Pref.

We have observed 254 stomach cancer patients who have undergone operation in the last thirteen years at our hospital, which is located in the mountainous region of Gifu prefecture in central Japan. Of the 254 patients, $62 \%$ or 159 were farmers and 95 were non-farmers.

Table 1. Cancer Patients

\begin{tabular}{l|c|c|c}
\hline \hline & Male & Female & Total \\
\hline Farmer & 112 & 47 & 159 \\
\hline Non-farmer & 65 & 30 & 95 \\
\hline Total & 177 & 77 & 254 \\
\hline
\end{tabular}

In our country, 40-50\% of stomach cancer patients in the rural areas undergo gastrectomy, while in the cities the percentage is 70 .

In our case there is no significant difference between farmers and nonfarmers; the rate being $56.6 \%$ for farmers and $51.6 \%$ for non-farmers. The rate of gastrectomy has improved some in recent years, in our case, but not remarkably. This low rate is still due to the large number of incurable patients who

Table 2. Rate of Gastrectomy in Japan

\begin{tabular}{l|c}
\hline Rural area & $40-50 \%$ \\
\hline City & $70 \%$ \\
\hline
\end{tabular}

Rate of Gastrectomy in Our Case

\begin{tabular}{l|c}
\hline Farmer & $56.6 \%$ \\
\hline Non-farmer & $51.6 \%$ \\
\hline
\end{tabular}


have delayed medical treatment. Incurable cases are somewhat more marked in the rural areas compared with the urban areas. The reason for this is that the farmers are not so aware of the symptoms of stomach cancer and in many cases do not know thay have cancer until the tumor has enlarged to a considerable size.

In our case, the survival rate of the gastrectomy farmer patients is somewhat lower compared with the non-farmers.

The rate for farmer patients who have a period of survival of over three years is $20.0 \%$, and for non-farmer patients $26.1 \%$.

The rates for patients who have a period of survival of over five years are $10.5 \%, 13.3 \%$ respectively.

Table 3. Survival Rate of Gastrectomy Patients

\begin{tabular}{l|c|c|c|c}
\hline \hline & $\begin{array}{l}\text { More than } \\
\text { 1 year }\end{array}$ & $\begin{array}{l}\text { More than } \\
\text { 2 years }\end{array}$ & $\begin{array}{l}\text { More than } \\
\text { 3 years }\end{array}$ & $\begin{array}{l}\text { More than } \\
\text { years }\end{array}$ \\
\hline Farmer & $45.8 \%$ & $27.2 \%$ & $20.0 \%$ & $10.5 \%$ \\
\hline Non-farmer & $59.2 \%$ & $34.0 \%$ & $26.1 \%$ & $13.3 \%$ \\
\hline
\end{tabular}

In our case, the rate of the size of tumor removed, which is larger than 40 sq.cm is $48.7 \mathrm{t} \%$ for farmer and $49.1 \%$ for non-farmers respectively-thus the high rate of incurability.

Table 4. Size of Tumor.

\begin{tabular}{l|c|c}
\hline \hline & Smaller than 40 sq.cm & Larger than 40 sq.cm \\
\hline Farmer & $51.3 \%$ & $48.7 \%$ \\
\hline Non-farmer & $50.9 \%$ & $49.1 \%$ \\
\hline
\end{tabular}

The relationship between the size of a tumor and the period of survival is as follows : if the size of the tumor removed is under 30 sq.cm, the surviving period is long, the smaller the tumor the longer the period of survival; but this relationship is undetectable when the tumor is over 30 sq.cm.

As early diagnosis and early operation are ideal for treating stomach cancer, group medical examination for cancer is very important in the rural areas.

In our country frequency of stomach cancer among inhabitants over 40 years 
Table 5. Size of Tumor and Period of Survival

\begin{tabular}{l|lllll}
\hline \hline Period of survival & $0-1$ year -2 years -3 years -5 years $\longrightarrow$ \\
\hline Farmer & 54.9 sq.cm & 57.0 sq.cm & 49.0 sq.cm & 29.8 sq.cm & 27.1 sq.cm \\
\hline Non-farmer & 53.7 sq.cm & 49.0 sq.cm & 79.8 sq.cm & 27.0 sq.cm & 19.0 sq.cm \\
\hline
\end{tabular}

old is higher in the country than in the city. The frequency is found to be about $0.1 \%$ in the urban areas and $0.6-0.7 \%$ in the rural areas. Namely, this is the result of the great number of cases in the country that have delayed in medical treatment. 